\title{
EGY ESZKÖZTELEN PEDAGÓGUS I.
}

\section{OSZTÁLYFŐNÖKÖM, JULISKA NÉNI}

\section{SzÉKELY RóBERTNÉ}

tanár

Az emlékek messzire vezetnek, két emberöltőnyit is repülnek visszafelé, egészen a könnyes, véres, zuhanó bombák zúgásával terhes, és mégis napfényes, sokszor mosolygós múlt század közepéig. Igen, mert akkor is sütött a nap, és mi vidámak voltunk, hiszen gyerekek voltunk. A múlt század dereka volt gyermek- és ifjúkorunk ideje, a már soha vissza nem térö.

Állunk az iskolaudvaron tízévesen, s ott áll közöttünk egy fiatal nő. A diplomáján tán meg sem száradt még a tinta: magyar-latin szakos középiskolai tanár. Mi, egy nagyobb fészekaljnyi gyerek - csupa kislány - bávatag szemekkel nézünk a fényképezőgép lencséjébe: alig tudunk még az életről valamit. Juliska néni - Horváth Julianna - szürke kosztümben, simán, egyetlen hullámmal hátrafésült hajjal - később is mindig így viselte - ott áll mellettünk. Talán még ő sem tudja igazán, mi az élet, de a tekintetében felelősség csillog: ez a gyerekcsapat az övé, ő felel értük. S valóban felelt értünk. Óráinkon mi neki jelentettünk: Osztályfőnöknek tisztelettel jelentem ..., de ,jelentett” ő is, egy benső és felső vezérnek. S mi, volt tanítványok, magunk is megöregedve már, mondhatjuk, Juliska néni kiállta a jelentéstevők próbáját.

Milyen volt ő? Elmondhatnám, hogy mint osztályfönökünk és tanárunk (első osztálya voltunk az egyetem elvégzése után) szinte második anyánk volt, aki nem csak tanított, nevelt, vigyázott is ránk. Kellett is vigyáznia, hisz volt, amikor az órán az iskolacsengő helyett a sziréna vijjogó hangja riasztott, és a gyerekcsapat riadtan vonult le a biztonságosnak vélt óvóhelyre, az iskola pincéjébe. Észrevette, ha valamelyikünknek láztól csillogott a szeme, vagy tornaóra után a harisnya harmonikázott a lábán. Patentharisnya, persze, nejlon akkor még nem létezett, selyemharisnyát pedig gyerekként nem viselhettünk.

Az iskola, a híres, nevezetes gimnázium patinája a még korábbi századra nyúlik vissza, s a maga nemében az első leánynevelő intézet volt Magyarországon. Igaz, a XX. század első felében már nemcsak nemesi sarjak leányai jártak oda, hanem polgárlányok is jócskán, de az öltözet, a Bocskai egyenruha és az illedelmes viselkedés egyaránt kötelező volt. Juliska néni, amikor még nem volt néni, maga is ebbe a gimnáziumba járt, s oda ment vissza tanítani. Akkor még nem tudta, haláláig. 
33 esztendő tanárként, majd újabb 30 nyugdíjasként járt vissza a testülethez és ragaszkodott a hajdani diákokhoz. Ez több mint 60 év, szolgálatban, ugyanazon a vártán!

Elmondhatnám, mennyire igényes, mindig következetes, követelö, ugyanakkor megértő ember volt. Talán ezért nem féltünk tőle soha, de meg kellett felelnünk mindannak, amit elérendő célként elénk állított. Árulkodás egymásra? A tanári figyelem kijátszása? Diákok közt szokásos, bocsánatos bünnek számító csalások? Oráin mindezek szóba sem jöhettek.

Szigorú tanár volt Juliska néni? Igen. Szigorú volt, ám szigora nem öncélú, hanem értünk való volt. Az iskola és következésképpen Juliska néni osztálya a jellemnevelés színtere volt, s persze, a tudás megszerzésének színtere is, így, együtt. Szellemi értékek és a jellemerő megszerzésének, növelésének helyszíne. Az osztály falai közé soha nem szürödött be az odakint dúló, egyre elvakultabb gyülölködés. Gondoljuk meg! 1942-t írtunk, amikor az osztály indult, s emlékeim szerint akadt tanár, aki nem egyformán nézett minden kislányra. Ám Juliska néninek mindannyian egyformák voltunk, származásra, anyagiakra, sőt, még képességekre való tekintet nélkül is. Csupán egyvalami számított, ám az nagyon erősen esett latba: a kötelességteljesítés. Ebben nem volt pardon. Jöhetett háború, üldöztetés, romokból újjáépítés, kitelepítés, egyik sem változtatott erkölcsi normáin, igényességén. Számára fontos tulajdonságnak számított az egyenesség, az őszinteség, a segítőkészség, a kölcsönös tisztelet egymás iránt. Ezt a kifejezést: egymásra hangolódás ő maga írja le az iskola akkori igazgatójáról, $d r$. Haitsch Ilonáról szóló írásában. Talán azért talált rá erre a szép szókapcsolatra, mert ez a viszony az ő tanítványaival való kapcsolatára is jellemző volt. Talán „eltanulta” az Országos Nőképző Egyesület Veres Pálné Leánygimnáziumának első női igazgatójától. Rá tudott és rá akart hangolódni a tanítványaira.

Mélyen vallásos életet élt, de oly szemérmesen volt hívő, hogy ezt a vonását csak a temetésén ismertem fel igazán. Soha nem akart senkit befolyásolni saját vallásos meggyőződésével.

Rendkívüli szerénység jellemezte. Mentes volt mindenfajta póztól. Öltözködése éppúgy, mint viselkedése, híján volt mindenféle harsány, figyelemfelhívó színnek, gesztusnak. Majdnem azt mondhatnám: minden eszköz, „,kellék” nélkül tanított. Ez azonban nem lenne igaz, mert ő maga volt az „eszköz”. Személyisége hordozta azokat a hatáselemeket, amelyekkel tanítványaira hatást gyakorolt. Az eszköztelenség, mint pedagógiai jellemző azért sem felel meg teljesen a valóságnak, mert mégis voltak eszközei: a könyvek. A könyvekröl és íróikról mindig nagyon szépen beszélt nekünk. Ízes, szép szavakkal, gazdag szókinccsel és mély érzelmi átéléssel. Ahogy jellemezte Aranyt, Petöfit, Kölcseyt, Vörösmartyt vagy az ókori latin költöket, ahogy felolvasta a verseket, mi, osztálytársak, mindannyian beleéltük magunkat a szavak ritmusa közvetítette gondolatokba és érzésekbe. Ma is emlékezünk ezekre a magyarórákra. Míg őt hallgattuk, fantáziánk élénken rajzolta ki a halott kis verebet, a szép Lesbiáét. Szinte ma is hallom a pergő dactylusok és spondaeusok ko- 
pogását: „...passer mortuus est meae puellae...”, ma is látom a szerelmes Catullust, aki megénekelte, mint ahogy látom Vörösmarty vén, öreg cigányát is.

E puritán, minden feltünést szinte a végletekig kerülő asszony oly mély beleéléssel, a szöveg olyan erős átélésével közvetített író, költő és fiatal hallgatósága között, hogy mi magunk is átéltük a szavak hordozta jelentést, láttuk a költői képeket - nyilvánvalóan mindenki saját belső világa szerint, mégis a költői akaratnak megfelelően. Így váltunk egy életre irodalmat, poézist szerető és értő emberekké. Eszköze volt saját hangja, beszédstílusa, ezzel volt képes, pusztán ezzel, a szavakon átsütő belső tủzzel szuggesztív hatást gyakorolni ránk. Nem tantárgyakat tanított, magyar irodalmat, ókori nyelvet, hanem az irodalom szeretetét, a múvek megértését, mindennapos igényt az írott szó közvetítette gondolatokra. Ízlést, ami segített elkülöníteni az értékest az értéktelentől. Müveltséget és kultúrát, ókori és „csak” múltbéli, vagy éppenséggel kortárs írók, költők müvein keresztül, sok-sok példát, helytállásra, igazmondásra, hüségre, hazaszeretetre és szeretetre, barátságra és szerelemre, mindenekelőtt és mindenekfelett mélységes humánumra. A müvek, melyekröl olvastunk, amelyek kapcsán fogalmazni tanultunk, és amelyeket elemeztünk, a miénkké váltak. Belső világunk alakítójává. Jól emlékszem egy kora tavaszi délelőttre az iskolaudvaron, - éppen $A d y t$ tanultuk - a vadsóska már virágba borult a kerítésen (ó, hogy kerestem ezt évtizedek múltán, a hajdan tágasnak érzett, de a valóságban akkorra már kicsivé zsugorodott iskolaudvaron, amikor unokám ballagására érkezvén, ismét ott álltam a tavaszi fényben), és engem eltöltött a szabadságnak, a világ tágasságának soha vissza nem térő érzése: „Március van, s határtalan az Élet!” Jöttek márciusok, tüzes márciusok is, de több ilyen, mint akkor, a jövő határtalanságának pillanatnyi megélésével, az Élet annyi, de annyi ígéretével teli, nem volt több soha az életemben.

Elmondhatnám tehát, hogy jó tanár volt. Nehéz körvonalazni, ez mit jelent. Talán minden korban kicsit mást, miközben a ,jótanárságnak” vannak közös elemei. Elengedhetetlen az emberség, a magas színvonalú szakmai tudás, és az az egyedülálló pedagógiai képesség, hogy ezt a tudást akarja és tudja is átadni a tanítványoknak. Elengedhetetlen a követelés is, a tanítványokkal szemben támasztott igényesség, mert ezek képviselik az útjelző táblákat, amerre haladnunk kell gyermekként, majd később, az életúton.

Nyolc évig voltunk együtt, osztálybontások, átszervezések, háborús és politikai viharok közepette, amikor 1948-ban Juliska néni egy ideig még megbízott igazgatója is lett a gimnáziumnak. Rövid időre, néhány hónapra csupán, mert ő nem iskolát vezetni akart, nem hatalmat akart, noha övé volt az emberek feletti hatalom egyik legnagyobbika, a felnőtt, az érett ember hatalma a gyengébbek, a fejlesztésre, a növelésre szorulók, az éretlenek felett. Ö egyszerúen „csak” tanítani akart. Tanítani, középiskolás fokon és azon túl.

A nyolc esztendő alatt mi kislányokból süldőlányok, bakfisok, majd nagylányok lettünk. Természetesen Juliska néni életébe is hozott változásokat ez a nyolc év: 
Horváth Juliannából Dr. Korompay Bertalanné lett, majd családanya, sorra születtek a gyermekei. Négyből három „a mi korszakunk” alatt. Ilyenkor néhány hónapra eltünt az iskolából. Ezen időszakokban olykor el-elcsíptünk szüleink aggodalmaskodó szavaiból néhány megjegyzést: Mi lesz az osztállyal? Semmi nem lett az osztállyal. Jó volt a vetés, szárba szökkentek a magvak. Juliska néni visszajött, és ment tovább az életünk, úgy, mint korábban.

Nem emlékszem, hogy valaha is a legkisebb konfliktus éleződött volna az osztály, a gyerekek és Juliska néni között, $\mathrm{s}$ ha adódott olykor ilyesmi más tanárokkal, ő segített elsimítani, kibogozni a megbántottság, a félreértések, olykor sértődések összekuszálódott fonalát. Természetesen volt arra is példa, hogy valamin, a fejlődő gyermeki jellembe vágó probléma kapcsán elcsúsztunk az emberi viszonylatok érzékeny talaján, és nem cselekedtünk helyesen, úgy, ahogy várta volna tölünk. Ilyenkor homlokán két piros folt gyúlt, a harag ott sütött a tekintetében. Ki ne igyekezett volna ilyenkor olyan gyorsan jóvátenni, amit vétett, amilyen gyorsan csak lehetett?

Elmondhatnám azt is, a gyermekei nevelése, a növekvő családban és az órákon való helytállás mellett jutott ideje önképzőkört szervezni, módszertannal foglalkozni, tanulmányokat készíteni, édesapja, dr. Horváth János irodalomtörténész professzor örökségét ápolni, hagyományokat teremteni. El kell mondanom, nyugdíjasként sem mondott le az iskola nimbuszának, hagyományainak építéséröl. Megalkotta és éveken át vezette a Volt Iskolatársak Szövetségét. Elmúlt már 80, ekkor már családtagjai kocsival hozták, vitték az iskolába, de nem adta fel az emlékek építését, a szálak tovább fonását iskola és öregdiákok között.

Mennyi mindent mondhatnék el még, hisz néhány mondatba belefér szinte egy egész élet. Sok élet, az övé és a miénk. Ám titkot keresek. Nem csupán méltatni őt, hanem megfejteni: mi volt a titka, hogy emléke az évtizedek múltán is oly élö. S e titkot kutatva újabb emlékképek jelennek meg a lélek sajátos, belső vetítővásznán, egy emlékfüzér inkább, ami csak az enyém, az én életemet meghatározó. Tavasz van. Ülünk az osztályteremben, kiröppenés előtt, matúrára váró lányok. A tavaszi fény a nagy ablaktáblákon bal felől hull ránk, aranyszínüre porozza a sötétkék iskolaköpenyt, a szőke, barna, fekete lányfejeket. Juliska néni elöttünk áll, kezében könyv - vagy csak lapok? - verset olvas. Az emlékezés most a hangját is idevarázsolja. Öt hallom:

„A mélyben néma, hallgató világok.

Üvölt a csönd fülemben, s felkiáltok

De nem felelhet senki rá a távol,

A háborúba ájult Szerbiából

$\mathrm{s}$ te messze vagy. Hangod befonja álmom, -

s szívemben nappal újra megtalálom, -

hát hallgatok, míg zsong körém felállván

sok hüvös érintésủ büszke páfrány." 
Mennyi szerelem, mennyi vágy, mennyi hüség van ezekben a sorokban! „Levél a hitveshez." Költöje nevét még nem hallottuk, hisz Radnóti akkor még nem volt hivatalos tananyag, de Juliska néni az osztály elé hozta és felolvasta nekünk a verseket, a Himnusz a békéről címüt, a Razglednicákat, a Hetedik eclogát és a többit. Ilyen modern volt ez a hagyományokat oly igen tisztelő ember! Még több is volt ennél: emberi és mondhatni, elvi-eszmei hitvallás volt ekkor Radnótit tanítani. Hányban is járunk ekkor? 1948-49-ben vagy tán 1950-ben? Versek, köztük nem rég előkerültek, a viharkabát zsebében megtalált, az elmúlás és a föld nedveivel átitatott noteszlapokon elmosódott betükkel írottak.

Azon a tavaszon én is szerelmes voltam. Akit szerettem, férjem lett. Akkor, abból a versből tanultam a vágyat a mély és igaz emberi kötésre férfi és nő között, a kötésre, mely átvezet még a halálon is. Juliska néninek köszönhetem, hogy Radnóti a legkedvesebb költőm lett. Elkísért egész életemben. Verseskötetei ott vannak könyvespolcomon. Gyüjtöttem a Radnótiról szóló irodalmat is, és a sors különös, furcsa szeszélyéből, ott tanítottam később biológiát és kémiát az Abonyi utcai gimnáziumban akkor, amikor Radnótiról elnevezték. Radnóti Miklós költészete, írásainak varázsa és így személyisége is az életem része lett. Életutam sok, olykor nehéz állomásán ködlöttek fel szavai és vigasztaltak meg költői képei, és a családomat egybefüző nem materiális „gének” szavakban, gondolatokban és érzésekben történő átvitelével jelenvalóvá váltak unokáim életében is. Radnóti titkát érteni vagy inkább érezni vélem. Ott van a verssorokban.

De mi a pedagógiai hatás titka? Mi emelte fel azt a régi, régi magyarórát oly magasságba, hogy fénye ma is bevilágítja életemet?

Úgy tartjuk, a pedagógiai hatás egyik fő alkotó eleme a személyiség varázsa, karizmája, szuggesztív ereje. Vajon miböl áll ez? Megfogható? Leírható?

Nyilván sokféle összetevője van. Talán egyik legkiemelkedőbb elem a hitelesség. Ha a pedagógus maga is megéli, amit tanít, és úgy él, miként másoktól megköveteli, vagyis egy lesz azzal, amit tanít, amit képvisel, hitelessé válik. Ismerjük ezt, példamutatásnak, mintának is nevezik. A hivalkodóan példamutató magatartást azonban senki nem követi. Kell, hogy vonzó személyiségvonásokkal társuljon a viselkedési minta.

Az viszont, ami vonzó, mindenki számára más. Így aztán a pedagógiai hatás többféle tényező szerencsés egybeesése, koincidenciája lehet. Hasonlatos ahhoz a sajátos együttálláshoz, amely speciális, kivételes, olykor rendkívüli esetekben az égitesteknél jön létre. Csak ott fénylik fel a Nap fényesen izzó koronája, ahol a Föld Hold - Nap együttállása ezt lehetővé teszi. Csak ott, akkor és kizárólag abban a szögben jelentkezik, ahol és amikor ezt a három égitest konstellációja megengedi. Ebben a metaforában a pedagógusok és a tanítványok is csillagok, fénylő lelkủ emberi lények. Befolyásolható ez az együttállás? Akarható? Kialakítható? Maga a találkozás talán nem. Ez lehet a véletlen müve. Ám a személyiség felvillanásai, vagy folyamatos ragyogása a következetes, mindig egyértelmü, imázzsá vált megnyilat- 
kozások során át, azon tulajdonságok során át, amelyek volt osztályfőnökömet jellemezték, a konstelláció majdnem biztosan létrejön.

Van azonban még egy feltétel: csak akkor, ha van fogadó. Ha van valaki, aki épp a fogékonyság eme varázslatos állapotában van. A gyermek lénye pedig szinte mindig ebben az állapotban van, a gyermeki lét különösen erősen fogékony a hatásokra - a rossz hatásokra is, sajnos. Amit megél és megtapasztal, életre szóló emléknyomokat hagy, mely befolyásolja nemcsak későbbi érzelmeit, hanem magatartását is. Ezért nagy a mi felelősségünk.

A mindent összegezni és elvonatkoztatni vágyó emberi elme megpróbálja hüvös egyenletbe foglalni a tapasztalatot és ennek talaján az elképzelést: a pedagógiai hatás karizmatikus ember, a tanár és fogékony lelkü fiatalok, a tanítványok szerencsés, olykor varázslatos találkozása, életük egy meghatározott, adott szakaszában.

Ebben az egyenletben marad még épp elég ismeretlen tényező. Miért épp ö? Miért épp akkor? Miért épp úgy? S mikor manifesztálódnak e hatások? A válasz titok marad, az emberi kapcsolatok örök és gyönyörü titka.

Megfejtése nélkül is követhetjük a mintát. Megpróbálhatunk olyanná válni, leendő és mai, sokszor tán már megfáradt, olykor már kiégett tanítók, tanárok, mint az a csillag volt, aki ugyan kilobbant már, de fénye, hatása még ott ég mibennünk.

Köszönet régi osztálytársaimnak, Bécsy Cecíliának, Jankovich Erzsikének, Láng Mártinak, Palotai Évának, Székely Évának, de mindenekelött Turza Rózsikának, hogy segítettek emlékeim felelevenítésében és ébren tartásában. Köszönet Gráberné Bösze Klára könyvtáros tanárnak, amiért az adatokat és a szakirodalmat rendelkezésemre bocsátotta. 